\title{
The sunflower moth, Homoeosoma nebulella (Denis et Schiffermüller ) (Lepidoptera: Pyralidae): outbreaks and pest management in Linhe, Inner Mongolia 2007-2008
}

\author{
Ling Z. Cao, Xiao X. Liu \& Qing W. Zhang
}

\begin{abstract}
Cao, L. Z., Liu, X. X. \& Zhang, Q. W. 2010: The sunflower moth, Homoeosoma nebulella (Denis et Schiffermüller) (Lepidoptera: Pyralidae): outbreaks and pest management in Linhe, Inner Mongolia 2007-2008. — Entomol. Fennica 21: 6569.
\end{abstract}

Sunflower moth Homoeosoma nebulella is the most common pest of sunflowers (Helianthus annuus L.) in China. A large outbreak involving H. nebulella was discovered in Linhe of the Mongolia Autonomous Region in 2007. Different issues related to pest management were investigated in 2007-2008. Irrigation for overwintering could promote pest outbreak in the following year. It is the safest practice to sow from mid-May to mid-June, i.e. not too early. The quantity of larvae could be reduced by the treatment with Bacillus thuringiensis. The effective pest management should include selecting proper sowing date, non-irrigation and $B$. thuringiensis treatment. Sex pheromone trapping as a potential control measure requires further studies.

L. Z. Cao, X. X. Liu \& Q.W. Zhang, College of Agriculture and Biotechnology, China Agricultural University, 100193, Beijing, China; E-mails (respectively): clzclz1011@163.com or clzclz1011@126.com, liuxiaoxia611@sohu.com, zhangqingwen@263.net

Received 9 November 2009, accepted 29 March 2010

\section{Introduction}

The sunflower moth, Homoeosoma nebulella, is a Palaearctic species and has a wide distribution from Northern China to Western Europe (Zagatti et al. 1991). In Linhe (105.12-109.53 ${ }^{\circ} \mathrm{E}, 40.13-$ $\left.42.28^{\circ} \mathrm{N}^{\prime}\right)$ of the Inner Mongolia Autonomous Region, an outbreak of sunflower moth caused striking economic losses in 2007. About 18.3 thousand hectares suffered infestation, of which 1730 hectares with no harvest corresponding with 24 million Yuan (2.58 million Euros) economic losses. For another 16.5 thousand hectares, the infestation rate was about 20-60 percent with 90 million Yuan (9.67 million Euros) economic losses. Additional areas also suffered different degrees of damage. The total economic loss reached about 0.2 billion Yuan (21.48 million Euros) this year (data of Linhe City Plant Protection Station).

Earlier articles on $H$. nebulella are mainly focused on the field surveys, chemical treatment (Teetes \& Randolph 1969, Beregovoy 1985a, b), synthesis of sex pheromones, behavior (Carlson et al. 1978, Metayer et al. 1991, Barker 1997) and morphology (Faucheux 1995). However, there is little information about the correlation between the occurrence of the pest and the external environmental conditions, and its control by agricultural and biological means. There has been increasing interest subsequently in the control of sunflower moth in sunflower plantations. In this 
study, the objectives were to find out the factors contributing to this outbreak, to control the pest under the economic threshold, and to provide new ideas and methods for integrated pest management.

\section{Materials and methods}

\subsection{Study species}

In Linhe, the first generation of moths began to emerge in early July and the second generation ones in August. The life cycle of the sunflower moth is as follows: eggs hatch within 3-5 days, larval period ( 4 instars) is 22 days, larvae pupate in soil for 6-7 days, and the flight period of adults lasts for 7-10 days. The females of $H$. nebulella oviposit in cultivated sunflowers as soon as blooming begins. The eggs hatch and the young larvae soon tunnel into the developing heads and feed on the floral structures and the developing seeds. At the same time, larval feeding also contributes to secondary infection by rhizopus head rot (Royer \& Walgenbach 1987). One larva can damage an average of nine seeds during its development (Wilson 1990). When mature, the larvae spin down to the ground and enter the soil where they form a silken cocoon.

\subsection{Field experiments}

The study sites (cultivated sunflower fields) were located in Wuyuan town $\left(108.28^{\circ} \mathrm{E}, 41.12^{\circ} \mathrm{N}\right)$ of Linhe in 2007-2008. There were 34 fields totally and each field, about $667 \mathrm{~m}^{2}$, was isolated at least one kilometer. Five plots were usually selected in each field. All fields have to be irrigated after the harvest in Linhe. Otherwise the following year crops (except for sunflower) will not be planted because of water shortage. So irrigation was regarded as a treatment in our study.

There were 12 fields, 6 fields, 8 fields and 8 fields in the sowing date, sex pheromone, the irrigation and the $B$. thuringiensis trial, respectively. There were 3 replicates for the first two treatments and 4 replicates for the latter two treatments. The sunflowers were planted from March to June. Due to planting time differences, there were sunflowers blooming from mid-July to early September. Sunflower harvesting began in October. The sunflowers were about 150-180 cm and they grew about $40 \mathrm{~cm}$ apart in rows, $50-80$ $\mathrm{cm}$ between rows.

\subsection{Effect of irrigation on pest outbreaks}

The trial was carried out in irrigated and non-irrigated fields in October 2007 and April 2008. The experiments in 2007 and 2008 were done in the same fields but different plots. Four fields were irrigated and four fields were not irrigated for the trial of 2008. Five plots of about $1 \mathrm{~m}^{2}$ were selected in each field. In the analyses, the mean value of the five plots was used for each field.

The soil of the fields was excavated for screening of pupae. Cocoon quantities were counted by digging $20 \mathrm{~cm}$ deep and sieving soil in each selected point. The brown pupae were wrapped with a thick layer of cocoon. The white cocoon is spindle-shaped.

\subsection{Effect of sowing date on pest outbreaks}

The sunflowers used in the experiment were planted by farmers in 2007. The sunflowers of different sowing dates were in different fields. Four planting times (mid-March, mid-April, midMay and mid-June) were selected in the trial. Twelve fields were selected according to the sowing time and other factors.

\subsection{Sex pheromone trapping and effect of Bacillus thuringiensis treatment}

Sex pheromone was applied in an attempt to trap sunflower male moths. The pheromone was synthesized by Sino-Czech Trading Co., Ltd in Beijing and contained four major components, (Z)-9tetradecenal, (Z,E)-9,12-tetradecadienal, (Z)-11hexadecenal, and (Z)-13-octadecenal.

Plastic basins baited with red rubber septum dispensers were used for this study. Each yellow basin was $24 \mathrm{~cm}$ in diameter and contained a water/detergent mixture to capture $H$. nebulella moths. The rubber septum dispenser was fixed 2 


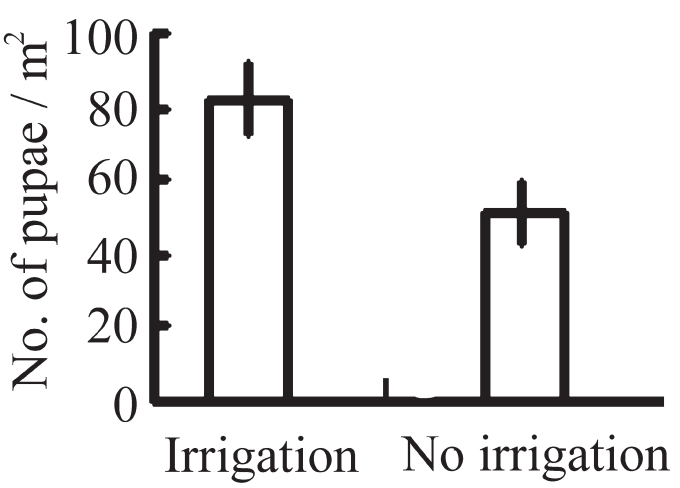

Fig. 1. Numbers (mean \pm S.E.) of overwintered sunflower moth, Homoeosoma nebulellum, pupae in two irrigation treatments ( $N=4$ fields per treatment) in 2008. The difference between the treatments is significant $\left(F_{1,6}=72.1, p<0.001\right)$.

$\mathrm{cm}$ above water surface in the basin, and all the basins were placed $150 \mathrm{~cm}$ above the ground at the intervals of $100 \mathrm{~m}$ distance. The catches were recorded every three days, and the results were expressed as the mean number of males caught per trap. Three sex pheromone traps were placed in each field.

Bacillus thuringiensis was applied in order to suppress the number of larvae. B. thuringiensis was provided by Wuhan Kernel Bio-pesticide Co. Ltd in Wuhan. The Bt toxins were diluted at 1:400, and then sprayed three times during the flowering period of $20 \%, 60 \%$ and $100 \%$ plant flowering, respectively (Depew 1983). The distance between the different treatments was about $1 \mathrm{~km}$ apart.

\subsection{Sunflower damage criterion}

The damage criterion of sunflowers was more than five places covered with webbing and frass, or more than ten sunflower seeds eaten in each sunflower head (Mcleod 2002, Mundal et al. 2006). The numbers damaged were counted out of 25 sunflower heads on each plot.

\subsection{Statistical analysis}

All statistical analyses were performed using SPSS 16.0 with $p=0.05$ as the criterion for signifi-

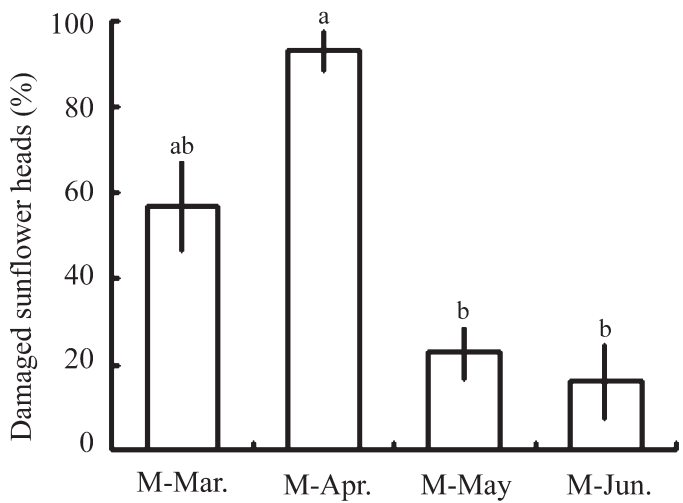

Fig. 2. Sunflower head infestation (mean \pm S.E.) by sunflower moths on four sowing dates $(N=3$ fields per treatment) in 2007. Different lowercase letters show significant differences among sampling dates $(p<0.05$; Duncan's multiple range test).

cance. Data were subjected to one-way ANOVA and Duncan's multiple range tests.

\section{Results}

\subsection{Effect of irrigation on pest outbreaks}

Before the irrigation in October 2007, there was no difference in the number of pupae between the fields of the two treatments $\left(F_{1,6}=0.44, p=0.53\right.$ ) whereas the number of overwintering pupae in the irrigated plots was more than that of the nonirrigated plots in April 2008 (Fig. 1).

\subsection{Effect of sowing dates on pest outbreaks}

There were significant differences in the number of damaged sunflower heads for the sunflowers with different sowing times in $2007\left(F_{3,12}=16.22\right.$, $p<0.001)$. Plots planted on mid-April showed severe damage while the plots planted on mid-May and mid-June showed low infestation. The infestation of sunflowers planted on mid-March was intermediate (Fig. 2).

\subsection{Sex pheromone trapping and effect of Bacillus thuringiensis treatment}

The mean catches of male moths per pheromone trap in 2007 are shown in Fig. 3. The peak catches 


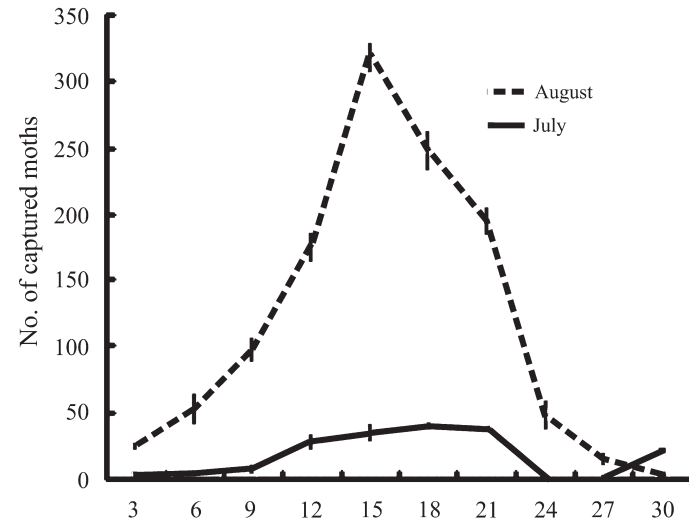

Fig. 3. Numbers (mean \pm S.E.) of sunflower moths captured by sex pheromone traps in July and August of 2007 ( $N=3$ fields per month).

occurred on 15 August. In July, the number of adults increased gradually, yet on 22-27 July there were none recorded because of the rain. $\mathrm{Bt}$ treatment decreased the number of sunflower heads damaged by $H$. nebulella (Fig. 4).

\section{Discussion}

The irrigation for overwintering could increase the sunflower moth quantities in the following year. Floods also increase moisture and temperature of the soil, which may aid the survival of the overwintering pupae. The result did not accord

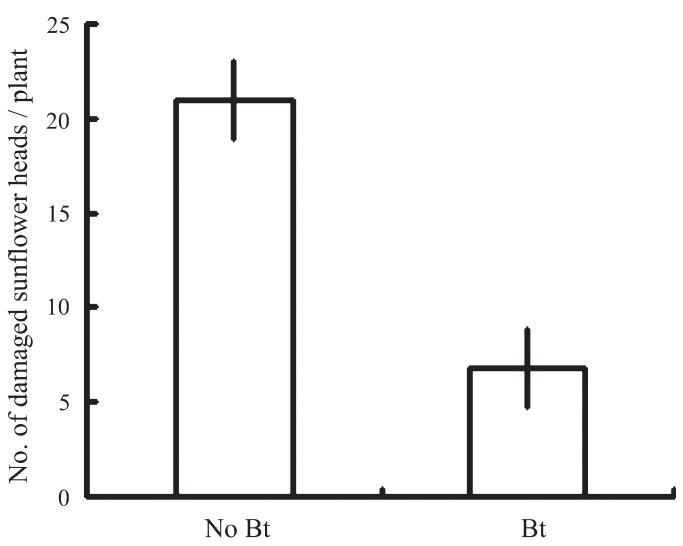

Fig. 4. Sunflower moth infestation (mean $\pm S$.E.) in two Bacillus thuringiensis $(\mathrm{Bt})$ treatments $(N=4$ fields per treatment). The difference between the treatments is significant $\left(F_{1,6}=46.2, p<0.001\right)$. with previous reports (Tran \& Takagi 2007, Yu et al. 2008). A possible reason is that our experiments were done in fields whereas the previous studies in the laboratory.

Sunflowers with late sowing were infested slightly in our study. This may be because of the lack of synchronization between flowering and moth oviposition. There are some similar reports about this (Oseto et al. 1989, Muhammad \& Gerald 1991). However, the effective accumulated temperature decreases gradually after August in Linhe, which will result in the reduction of sunflower yields. So the optimal sowing date requires further study.

Conventional insecticides are effective for the control of sunflower moth. The yields have been increased significantly in plots treated with insecticides, following three applications (Bynum et al. 1985, Charlet \& Busacca 1986). However, three applications at 5-7 day intervals will greatly add to the workload of the planters and the costs of production. In addition, pesticide misuse harms the environment and human health. It is generally inadvisable to use conventional insecticides for the control of sunflower moth, especially because the biocontrol and agricultural control was very effective for suppressing the population abundances of sunflower moths and larvae in our experiments.

Based on the catches during July and August in 2007, pheromone traps could be used to suppress the male moth abundances and forecast the moth peak (Kovanci \& Walgenbach 2005). The largest number of moths was ensnared in midAugust, which may represent the peak of the second generation. It is an important fact that planting time is not very consistent in Linhe. This may offer suitable hosts for moths at different periods of eclosion and produce large numbers of F1 generation, which may relate with pest outbreaks.

According to this study, the pest management of $H$. nebulella should include biological (here, Bt toxins) plus agricultural (here, unirrigation treament and proper planting date, i.e. flowering period should not coincide with moth eclosion) control. Sex pheromone traps should be used at the end of June in order to kill male moths. However, there is a limitation for this study that the relationship between yield loss and the percentage of the infestation of sunflower heads was not in- 
vestigated. This will be the subject of future studies.

Acknowledgements. We thank the workers in Linhe City Plant Protection Station who provided much help in our experiment. This work was funded by "973" project (No. 2006CB100204) and National support for projects (No. 2006 BAD08A07-5).

\section{References}

Barker, J. F. 1997: Oviposition by the banded sunflower moth (Lepidoptera: Cochylidae) in response to constituents of the bracts and leaves of Helianthus annuus. — Journal of Economic Entomology 90: 160-164.

Beregovoy, V. H. 1985a: Parasitism of the sunflower moth, Homoeosoma electellum (Hulst) (Lepidoptera: Pyralidae) in the Central United States. - Journal of the Kansas Entomological Society 58: 732-736.

Beregovoy, V. H. 1985b: Appearance of first generation larvae of the sunflower moth, Homoeosoma electellum (Hulst) (Lepidoptera: Pyralidae), in the Central United States. - Journal of the Kansas Entomologica Society 58: 739-742.

Bynum, E. D., Rogers, C. E. \& Archer, T. L. 1985: Evaluation of new insecticide application strategies for controlling the sunflower moth (Lepidoptera: Pyralidae) on sunflower. - Journal of Economic Entomology 78: 933-936.

Carlson, E. C., Witt, R. L. \& Miller, J. C. 1978: Tracing the flight activity of the sunflower moth [Homoeosoma electellum ]. - California Agriculture 32: 8-9.

Charlet, L. D. \& Busacca, J. D. 1986: Insecticidal control of banded sunflower moth, Cochylis hospes (Lepidoptera: Cochylidae), larvae at different sunflower growth stages and dates of planting in North Dakota. - Journal of Economic Entomology 79: 648-650.

Depew, L. J. 1983: Sunflower moth: oviposition and chemical control of larvae on sunflower. - Journal of Economic Entomology 76: 1164-1166.

Faucheux, M. J. 1995: Sensilla on the larval antennae and mouthparts of the European sunflower moth, Homoeosoma nebulella Den. and Schiff(Lepidoptera: Pyralidae). - International Journal of Insect Morphology and Embryology 24: 391-403.

Kovanci, O. B. \& Walgenbach, J. F. 2005: Monitoring the oriental Fruit Moth with pheromone and bait traps in apple orchards under different management regimes. - International Journal of Pest Management 24: 273 279.

Metayer, M. L., Thiery, D., Pham-delegue, M. H. \& Masson, C. 1991: Viposition Behavior and Locomotor Activity of Homoeosoma nebulellum (Lepidoptera: Pyralidae) Under Laboratory Conditions. - Environmental Entomology 20: 615-619.

Mcleod, M. 2002: Sunflower Moths \& Banded Sunflower Moths. - [www document] URL http://agbiopubs.sdstate.edu /articles/FS895.pdf. (Site visited on June, 2002).

Muhammad, A. \& Gerald, E. W. 1991: Sunflower moth control on sunflower planted on different dates in Kansas. - Journal of the Kansas Entomological Society 64: $51-59$.

Mundal, K. D., Brewer, G. J., Charlet, L. D. \& Knodel, J. J. 2006: Banded sunflower moth. - [www document] URL http://www.ag.ndsu.edu. (Site visited on November, 2006).

Oseto, C. Y., Charlet, L. D. \& Busacca, J. D. 1989: Effects of planting date on damage caused by the banded sunflower moth (Lepidoptera: Cochylidae) in the Northern Great Plains. - Journal of Economic Entomology 82: 910-912.

Royer, T. A. \& Walgenbach, D. D. 1987: Impact of sunflower moth (Lepidoptera: Pyralidae) larval infestations on yield of cultivated sunflowers. - Journal of Economic Entomology 80: 1297-1301.

Teetes, G. L. \& Randolph, N. M. 1969: Chemical and cultural control of the sunflower moth in Texas. - Journal of Economic Entomology 62: 1444-1447.

Tran, D. H. \& Takagi, M. 2007: Effects of low temperatures on pupal survival of the stone leek lea fiminer $\mathrm{Li}$ riomyza chinensis. - International Journal of Pest Management 53: 253-257.

Wilson, R. L. 1990: Rearing the sunflower moth (Lepidoptera: Pyralidae) for use in field evaluation of sunflower germplasm. - Journal of the Kansas Entomological Society $63: 208-210$.

Yu, F. L., Wu, G., Liu, T., Zai, B. P. \& Chen, F. J. 2008: Effect of irrigation on the performance of cotton bollworm, Helicoverpa armigera during different pupal stages. - International Journal of Pest Management 54: $137-142$.

Zagatti, P., Renou, M., Malosse, C. \& Frerot, B. 1991: Sex pheromone of the European sunflower moth, Homoeosoma nebulellum. - Journal of Chemical Ecology 17: 1399-1415. 